J. Natn. Sci. Coun. Sri Lanka 198412 (2) : 191-203

\title{
Seasonal and Diurnal Variation in Thermal Comfort in Sri Lanka
}

\author{
V. BASNAYAKE \\ Faculty of Medicine, University of Peradeniya, Peradeniya, Sri Lanka
}

(Date of receipt: $19 \mathrm{July} \mathrm{1984)}$

(Date of acceptance: 19 October 1984)

\begin{abstract}
The present work reports evidence bearing on the question whether seasonal acclimatization occurs in thermal comfort in a tropical country (Sri Lanka) where the seasonal change of temperature is small. Thermal comfort votes were taken in each of two subjects on nearly a hundred occasions over a period of $10-12$ consecutive months. One of the subjects also had records which had been taken 12 years previously over a period of six consecutive months. The ambient temperature level which was compatible with a sensation of satisfactory thermal comfort (comfort temperature) rose in the warmer season and fell in the less warm. Evidence is also presented on the question whether there is a seasonal variation in the effect which diurnal temperature change has upon thermal comfort. The change in thermal comfort from morning to afternoon was recorded in one subject on 73 days during a 12-month period. A seasonal acclimatizational effect was detected in which the change in ambient temperature which produced thermal discomfort was found to be larger in the warmer than in the less warm months. The effective temperature scale was noticed to be no better than the dry bulb temperature in demonstrating these seasonal acclimatizational effects.
\end{abstract}

\section{Introduction}

The ambient temperature level at which individuals feel thermally comfortable shifts with the seasons of the year. It shifts upwards in the hotter season and downwards in the colder. This seasonal shift of the preferred temperature for thermal comfort has been noticed in all climates which have been studied. In temperate climates the zone of comfort temperature shifts upwards in summer and downwards in winter. In the U.S.A. the winter comfort zone extends over an effective temperature range of $17.2-21.7{ }^{\circ} \mathrm{C}\left(63-71^{\circ} \mathrm{F}\right)$, midpoint $18.9{ }^{\circ} \mathrm{C}\left(66^{\circ} \mathrm{F}\right)$, while the corresponding figures for the summer comfort zone are $18.9-23.9^{\circ} \mathrm{C}\left(66-75^{\circ} \mathrm{F}\right)$, midpoint $21.7^{\circ} \mathrm{C}\left(71^{\circ} \mathrm{F}\right) .{ }^{12}$ In the U.K. the midpoint of comfort temperature is $22^{\circ} \mathrm{C}$ effective temperature in summer and $17^{\circ} \mathrm{C}$ in winter.

Does the phenomenon of a seasonal shift of comfort temperature occur in 'monotonous' climates with only small changes in seasonal temperature? In the equatorial tropics the mean monthly temperature of the warmest month of the year is only about $5{ }^{\circ} \mathrm{C}\left(9^{\circ} \mathrm{F}\right)$ higher than that of the coolest month, with a mean annual temperature of about $27.7^{\circ} \mathrm{C}\left(80^{\circ} \mathrm{F}\right) .^{6}$ Tropical marine climates are similar to equatorial climates. In higher latitudes the temperature changes which occur from month to month are more marked and there may be a hot season ('summer') and a cold season ('winter'). The island of Sri Lanka, situated at $5-10^{\circ} \mathrm{N}$ latitude, has a practically equatorial climate. Referring to the absence of seasons in Sri Lanka 
by Western standards a British observer over a century ago wrote: "and fruit hangs ripe on the same branches that are garlanded with opening buds"10; and a still earlier observer spoke of "the perennial summer which it experiences (I cannot say enjoys)"'2. The mean annual temperature for its seaside capital, Colombo, is $26.9{ }^{\circ} \mathrm{C}$ $\left(80.5^{\circ} \mathrm{F}\right)$; the mean monthly temperature for the hottest month, May, is $27.9^{\circ} \mathrm{C}$ $\left(82.3^{\circ} \mathrm{F}\right)$ and that for the coolest month, December, $26.1^{\circ} \mathrm{C}\left(79.0^{\circ} \mathrm{F}\right)$, so that the difference between warmest and least warm months is $1.8^{\circ} \mathrm{C}$. In Kandy, which is at an altitude of about $500 \mathrm{~m}$ above mean sea level, the corresponding figures are a mean annual temperature of $24.4^{\circ} \mathrm{C}\left(75.9^{\circ} \mathrm{F}\right)$, hottest month, April, $26.0^{\circ} \mathrm{C}\left(78.8^{\circ} \mathrm{F}\right)$, coolest month, January, $23.1^{\circ} \mathrm{C}\left(73.6^{\circ} \mathrm{F}\right) .^{9}$ The purpose of the present work was to find out whether there was any seasonal shift of comfort temperature in so 'monotonous' a climate as that of Sri Lanka.

The diurnal changes in ambient temperature are, in tropical climates, more marked than the seasonal changes. The nights feel cooler than the daytime; there is a saying that 'night is the winter of the tropics'. The early afternoon usually has the highest temperature over a 24-hour period. In Sri Lanka the annual mean daily temperature range is about $6.1^{\circ} \mathrm{C}\left(11^{\circ} \mathrm{F}\right)$ for Colombo and $8.3^{\circ} \mathrm{C}\left(15^{\circ} \mathrm{F}\right)$ for Kandy. Would the comfort temperature shift with the diurnal change in ambient temperature? The available evidence is small and contradictory. A study in Calcutta collected records of ambient temperature and thermal comfort at $10 \mathrm{~h}, 12 \mathrm{~h}, 14 \mathrm{~h}$ and $16 \mathrm{~h}$ during the day twice a week throughout one year but the purpose of the study was to determine the comfort temperature range rather than to detect diurnal and seasonal effects. ${ }^{7}$ In the Australian tropics (Welpa, North Queensland) the upper limit of corrected effective temperature for thermal comfort was found to be less by night than day. ${ }^{13}$ The comfort temperature for British sailors serving in warships in tropical seas was the same for evening as for midday. Nor was the comfort temperature changed as a result of a sojourn in a cooler region (Japan). ${ }^{4}$ In the present study an attempt was made to compare the comfort temperature for morning with that for afternoon.

\section{Method}

The study was done in a physiology laboratory at Peradeniya, within the Kandy municipal limits.

Recordings were made of ambient temperature and thermal comfort in two subjects as occasion arose over a period of months. The observations fall into two series:- Series A, observations made on one subject (Subject I) during April September 1967 once a day at c.9.30h for a total of 40 days. The subject was a 41 - year old male. Series B, observations made during October 1978 - September 1979 in the same subject as above (Subject I, 53 years old by then), and during 1978 August 1979 in a 23-year old female (Subject II), at 9.30h. In series B the ambient temperature at $9.30 \mathrm{~h}$ was recorded on 170 days while thermal comfort was recorded 
on 95 occasions for Subject I and 91 for Subject II. In addition, recordings were also made at $14.30 \mathrm{~h}$ on 73 out of these 95 occasions for Subject I. All the measurements were made indoors in the laboratory with the subjects in the sedentary state and the clothing was customary light wear (shirt and long trousers for the man and frock for the woman).

Ambient temperature was measured as dry bulb temperature (DBT), wet bulb temperature (WBT) and effective temperature ( $\left.\mathrm{T}_{\text {eff }}\right)$. DBT and WBT were measured with a whirled pair of thermometers (whirling psychrometer). $T_{\text {eff }}$ was read from a nomogram for 'normal effective temperature' using data for air speed obtained with a katathermometer (dry, red spirit, 95-100 ${ }^{\circ} \mathrm{F}$ ).

Thermal comfort was recorded verbally on a seven-point scale: comfortable (grade 4), comfortably warm (grade 5), warm (grade 6), hot (7), comfortably cool (3), cool (2), cold (1). This scale closely follows the customary seven-point thermal comfort scales. ${ }^{1}$

In looking for seasonal effects, all the thermal comfort votes taken at $9.30 \mathrm{~h}$ were analysed month by month, separately for each of the two subjects. For each month all the votes which stated 'comfortable', 'comfortably warm', or 'comfortably cool' (grades 4, 5 and 3 respectively) were regarded as signifying a satisfactory state of thermal comfort. The corresponding ambient temperatures were regarded as 'comfort temperatures'. These 'comfort temperatures' for each month were then summarised as a median value and their range.

Diurnal effects were looked for in the 73 pairs of morning and afternoon readings which were available for Subject $I$. The analysis was done as follows: The difference in temperature $(\triangle T)$ between morning and afternoon was expressed as the afternoon temperature minus the morning temperature. The change in thermal comfort $(\triangle$ com $)$ from morning to afternoon was expressed as the afternoon rating minus the morning rating on the seven-point scale. (Thus a morning rating of comfortable, grade 4 on the seven-point scale, and an afternoon rating on the same day of warm, grade 6 , was counted as a change of +2 grades, i.e. deterioration in thermal comfort by two grades. A change from comfortably warm, grade 5 , in the morning to comfortably cool, grade 3 , in the afternoon was counted as -2 grades, i.e. an 'improvement' in the thermal comfort by two grades.) Finally the data for $\Delta$ com were tabulated in relation to $\Delta T$ in order to see whether the two could be related.

A seasonal effect was also looked for in the morning and afternoon pairs by tabulating $\triangle T$ and the number of occasions on which a deterioration in thermal comfort by two or more steps was recorded month by month. There was a total of 40 such occasions during the 73 days on which morning and afternoon readings were taken for Subject I. 


\section{Results and Conclusions}

\subsection{Season and comfort}

Table $1 \mathrm{a}$ and $1 \mathrm{~b}$ show the relation between comfort temperature $\left(\mathrm{T}_{\mathrm{com}}\right)$ and ambient temperature $\left(\mathrm{T}_{\mathrm{amb}}\right)$. $\quad \mathrm{T}_{\mathrm{com}}$ denotes the monthly median value for ambient temperature when the subject felt thermally comfortable (comfort temperature). $\mathbf{T}_{\mathrm{amb}}$ denotes the monthly median value for all readings of ambient temperature irrespective of comfort. Both sets of readings are from the 1978-79 study (Series B). Figure 1 shows the relation between $T_{c o m}$ and $T_{a m b}$ graphically.

TABLE 1a. Season and ambient temperature

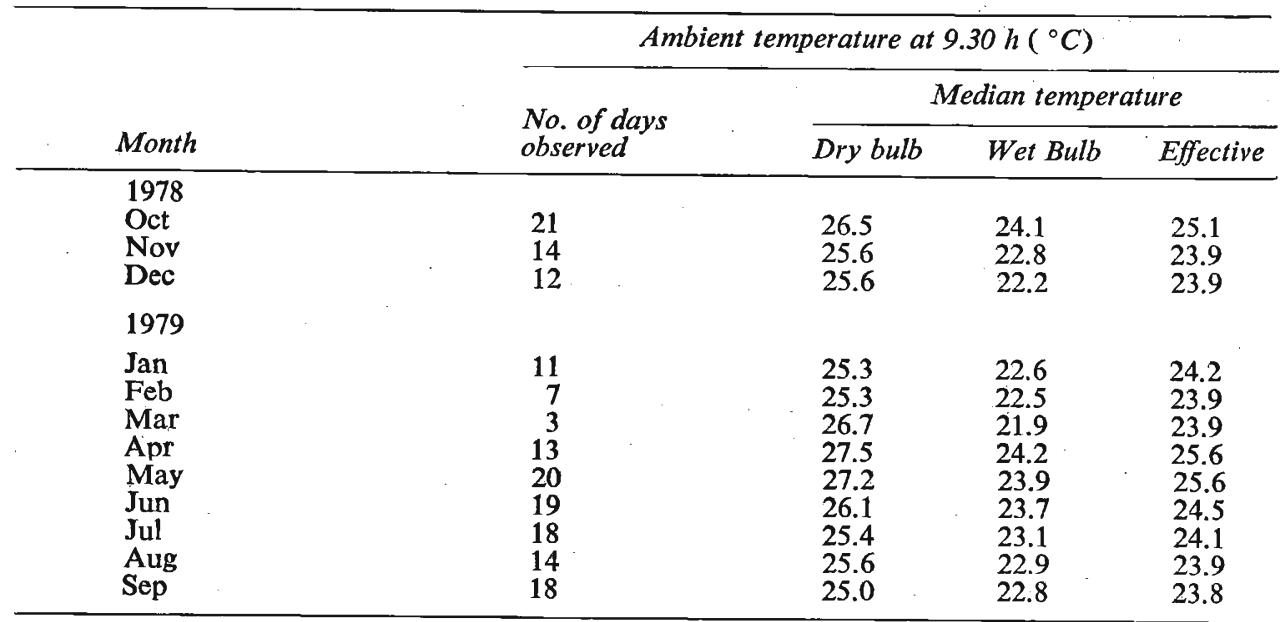

TABle 1b. Season and comfort temperature

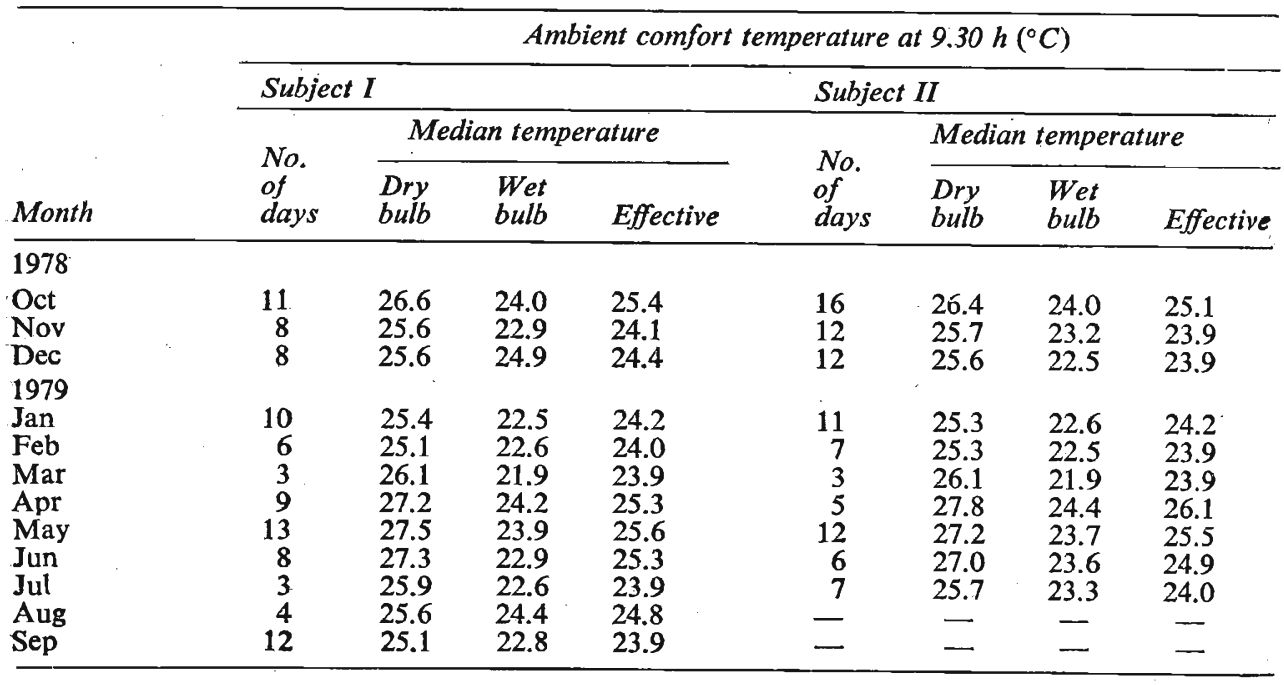



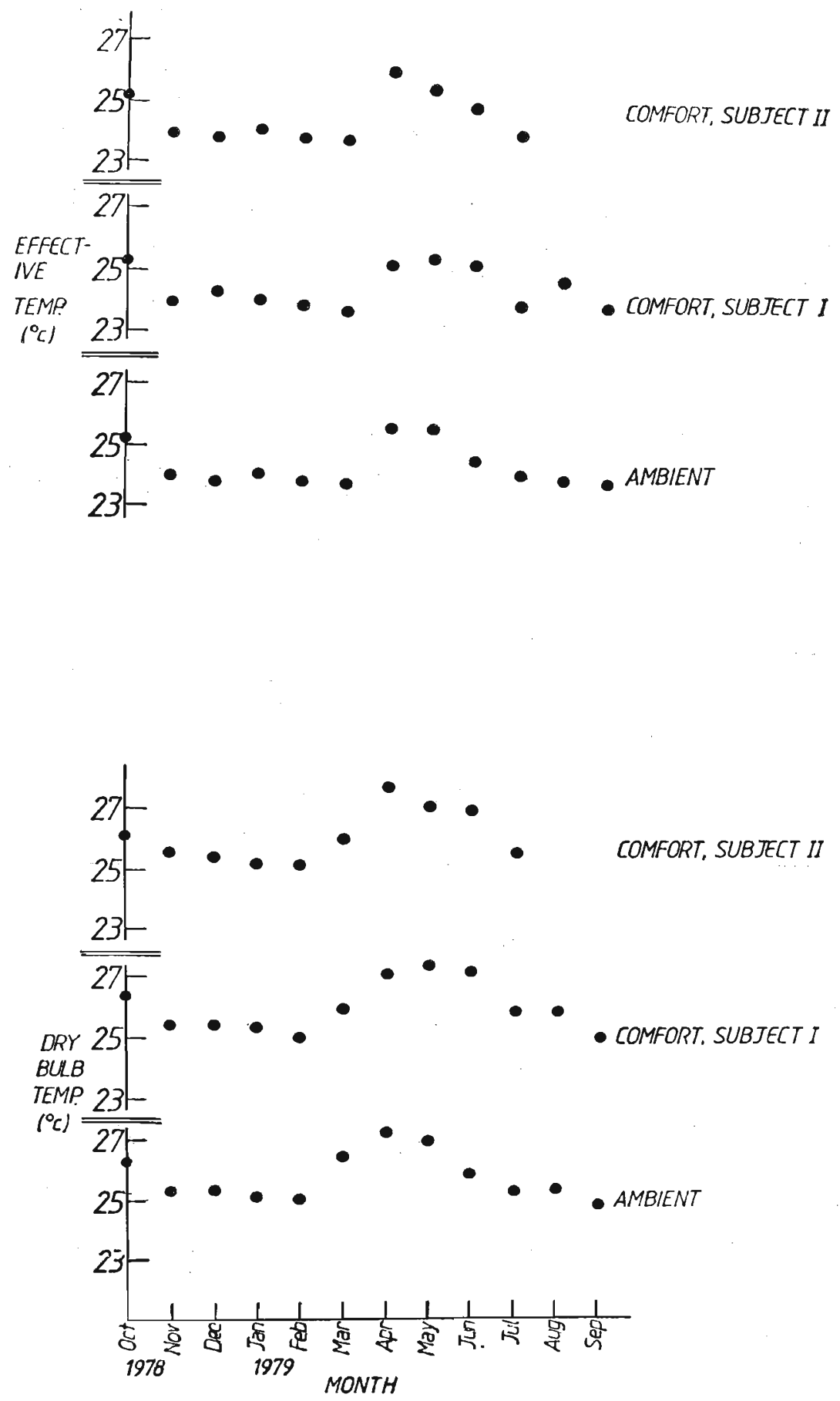

FigURE 1 - Season and thermal Comfort:

relation between monthly median ambient temperature and monthly median comfort te nperature in two individuals. 
There is a parallelism between the monthly comfort temperature and the ambient temperature.

Table 2 shows that the correlations between $T_{\text {amb }}$ and $T_{\text {com }}$ are highly significant for dry bulb temperature (DBT) and for effective temperature $\left(T_{\text {eff }}\right)$ but not for wet bulb temperature.(WBT). $T_{\text {eff }}$ is no better than DBT for demonstrating the parallelism.

TABLE 2. Correlation between median ambient temperature and median ambient comfort temperature

\begin{tabular}{llccc}
\hline Temperature & Subject & $\cdots$ & $r$ & $P$ \\
\hline Dry bulb temperature & I & 12 & +0.87 & $<0.001$ \\
& II & 10 & +0.91 & \\
Wet bulb temperature & I & 12 & +0.40 & $>0.1$ \\
& II & 10 & +0.97 & $<0.001$ \\
Effective temperature & I & 12 & +0.85 & $"$, \\
& II & 10 & +0.97 & $"$, \\
\hline
\end{tabular}

The shift of comfort temperature in parallel with ambient temperature amounts to a seasonal change: in the warm months, April, and May, comfort temperature is higher than in the other, less warm, months.

TABLE 3. Comfort temperature during corresponding successive months in 1967 and 1979 in Subject I

\begin{tabular}{lcccc}
\hline & \multicolumn{2}{l}{$\begin{array}{l}\text { No. of days on } \\
\text { which observations } \\
\text { were made }\end{array}$} & \multicolumn{2}{l}{$\begin{array}{l}\text { Effective temperature } \\
\text { at comfort } \\
\text { (Median value in }\end{array}$} \\
& 1967 & 1979 & 1967 & 1979 \\
\hline Apr & 5 & 9 & 26.9 & 25.3 \\
May & 3 & 13 & 25.2 & 25.6 \\
Jun & 2 & 8 & 25.3 & 25.3 \\
July & 7 & 3 & 23.5 & 23.9 \\
Aug & 3 & 4 & 24.4 & 24.8 \\
Sept & 4 & 12 & 24.8 & 23.9 \\
\hline
\end{tabular}

The data in the 1967 study (Series A) were fewer (Table 3), but the seasonal change in comfort temperature shows much the same pattern (Figure 2) in this one subject in recordings made 12 years apart. The correlation between the median $T_{\text {eff }}$ at comfort during April-September 1967 and that during April-September 1979 was $r=+0.66$, which, for these six pairs of readings, falls short of statistical significance $(\mathrm{P}>0.05<0.10)$. 


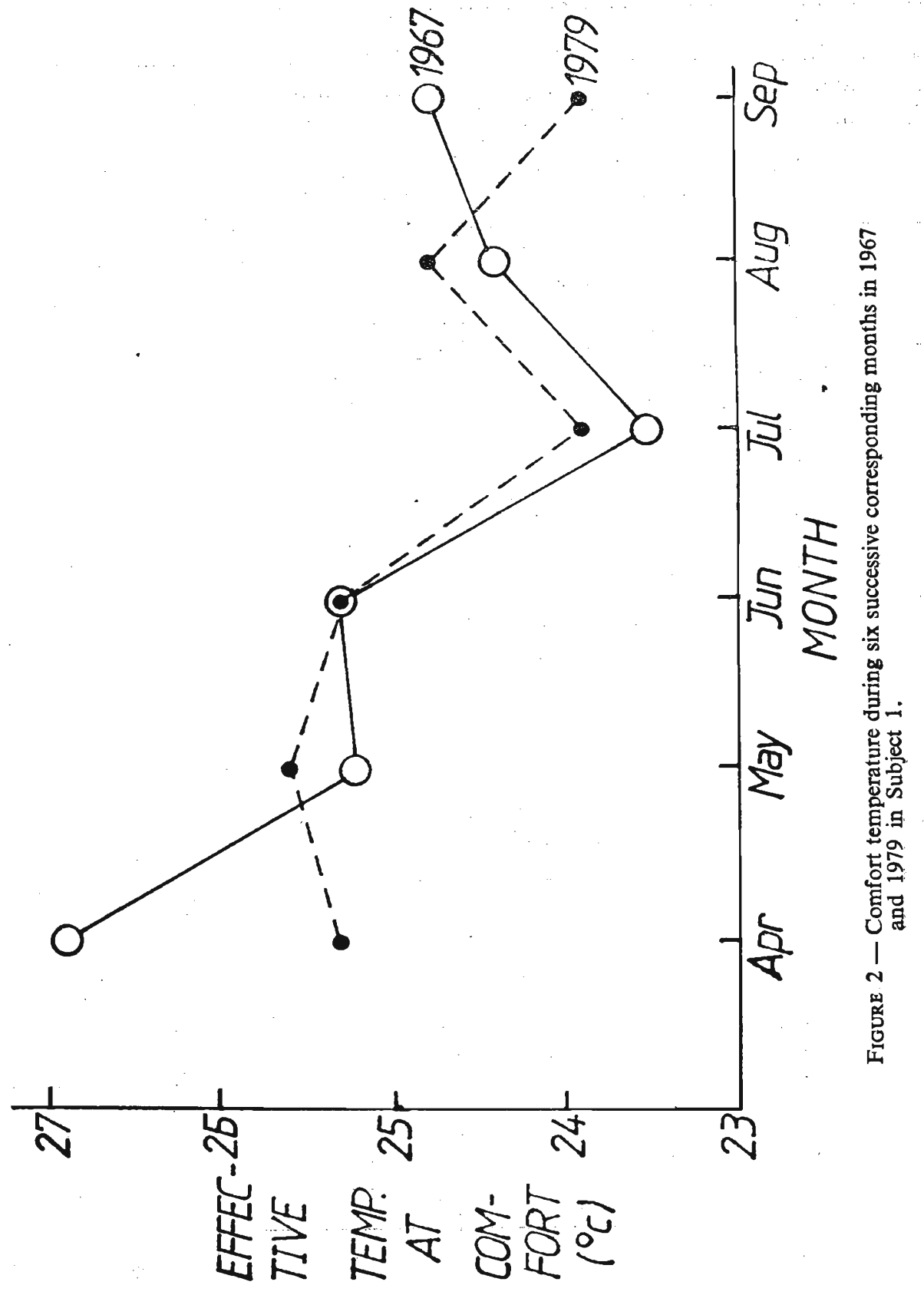




\subsection{Diurnal effects: morning vs afternoon}

The relation between the change in ambient temperature from morning to afternoon and the corresponding change in thermal comfort status is shown in Table 4 for ambient DBT and in Table 5 for ambient $T_{\text {eff. }}$.

TABLE 4. Diurnal change in thermal comfort ( $\triangle$ comfort) in relation to dry bulb temperature (DBT) in Subject 1

\begin{tabular}{lcccccc}
\hline $\begin{array}{l}\triangle \mathrm{DBT} \\
(\text { afternoon minus morning } \\
\text { reading })\left({ }^{\circ} \mathrm{C}\right)\end{array}$ & \multicolumn{5}{c}{$\begin{array}{l}\text { Frequency distribution of } \\
\text { (no. of steps on } 7 \text { - point scale })^{*}\end{array}$} \\
\hline$-1.0-$ & -2 & -1 & 0 & +1 & +2 & +3 \\
\hline $0.0-$ & 1 & 1 & 1 & - & - & - \\
$+1.0-$ & 1 & 1 & 4 & 3 & 7 & - \\
$+2.0-$ & 2 & 1 & 4 & 6 & 3 & 2 \\
$+3.0-$ & - & - & 3 & 1 & 8 & 1 \\
$+4.0-$ & - & - & - & 3 & 8 & 2 \\
$+5.0-$ & - & - & - & - & 3 & 2 \\
$+6.0-$ & - & - & - & - & 2 & 1 \\
\hline
\end{tabular}

* + denotes an increase in thermal comfort grade in the afternoon over that in the morning, i.e., a change towards the warm end of the scale.

-denotes the opposite, i.e. a change towards the cool end of the scale in the afternoon

TABLE 5. Diurnal change in thermal comfort ( $\triangle$ comfort) in relation to effective temperature $\left(T_{\text {eff }}\right)$ in Subject I

\begin{tabular}{|c|c|c|c|c|c|c|}
\hline \multirow{2}{*}{$\begin{array}{l}\triangle T_{\text {eff }} \\
\text { (afternoon minus morning } \\
\text { reading) }(\circ \mathrm{C})\end{array}$} & \multicolumn{5}{|c|}{$\begin{array}{l}\text { Frequency distribution of } \triangle \text { comfort } \\
\text { (no. of steps on } 7 \text { - point scale })^{*}\end{array}$} & \multirow[b]{2}{*}{+3} \\
\hline & -2 & -1 & 0 & +1 & +2 & \\
\hline-3.0 & - & 1 & - & - & - & - \\
\hline-2.0 & 一 & - & 1 & - & - & - \\
\hline-1.0 & 1 & - & - & - & - & - \\
\hline 0.0 & 3 & 2 & 7 & 6 & 7 & 1 \\
\hline+1.0 & 一 & - & 2 & 6 & 12 & 3 \\
\hline+2.0 & - & - & 2 & 1 & 8 & 2 \\
\hline+3.0 & - & - & 一 & - & 3 & 3 \\
\hline+4.0 & - & - & - & - & - & 1 \\
\hline
\end{tabular}

* + denotes an increase in thermal comfort grade in the afternoon over that in the morning, i.e., a change towards the warm end of the scale.

-denotes the opposite, i.e. a change towards the cool end of the scale in the afternoon. 
As the ambient temperature rose in the afternoon the thermal comfort status tended to deteriorate. Variability was considerable: anything could happen to thermal comfort when the rise of ambient temperature was less than $1^{\circ} \mathrm{C} \mathrm{T}_{\text {cff }}$ or less than $2^{\circ} \mathrm{C}$ DBT. It is accordingly difficult to quantify the effect of the afternoon rise of $T_{a m b}$ upon thermal comfort. General inspection of Tables 4 and 5 suggests a rough approximation: the deterioration in thermal comfort in the afternoon is likely to be about one grade (e.g. from comfortably warm to warm, or from comfortable to comfortably warm) when the DBT rises by about $1.5^{\circ} \mathrm{C}$ in the afternoon over that in the morning; the deterioration is likely to be two grades (e.g. from comfortable to warm) for a rise of about $2.5^{\circ} \mathrm{C}$; and three grades (e.g. from comfortable to hot) for about $3.5^{\circ} \mathrm{C}$. The corresponding figures for $\mathrm{T}_{\text {eff }}$ are about $\mathrm{I}^{\circ} \mathrm{C}, 1-2^{\circ} \mathrm{C}$ and $2^{\circ} \mathrm{C}$ or more, respectively.

It can also be seen that when the afternoon temperature fell below the morning temperature, as on a cloudy rainy afternoon, thermal comfort status tended to improve. The data are too few to look for further relationships.

$\mathrm{T}_{\text {eff }}$ does not appear to give a distinctly cleaner prediction of the change in comfort than does DBT.

\subsection{Seasonal-diurnal effects}

The change of ambient temperature $(\triangle T)$ from morning to afternoon which went with a deterioration in thermal comfort by two or three grades (no greater degree of deterioration was noticed) is shown in Tables 6 and 7. The data suggest that in April and May, which are the warmest months, $\triangle \mathrm{T}$ is of the order of $2-4^{\circ} \mathrm{C}$ DBT (Table 6) and $2-3^{\circ} \mathrm{C} \mathrm{T}_{\text {eff }}$ (Table 7) while it is of the order of $1^{\circ} \mathrm{C}$ for the other less warm, months.

TABLE 6. Seasonal effect in thermal comfort deterioration in the afternoon, in relation to dry bulb temperature (DBT)

\begin{tabular}{|c|c|c|c|c|c|c|c|c|c|c|c|c|}
\hline \multirow{2}{*}{$\begin{array}{l}\triangle \mathrm{DBT} \\
\text { afternoon } \\
\text { minus morning } \\
\text { reading }(\mathrm{oC})\end{array}$} & \multirow{2}{*}{$\begin{array}{c}1978 \\
\text { Oct }\end{array}$} & \multicolumn{11}{|c|}{$\begin{array}{l}\text { No. of occasions on which deterioration* occurred } \\
1979\end{array}$} \\
\hline & & Nov & Dec & Jan & $\mathrm{Feb}$ & Mar & $A p r$ & May & Jun & Jul & Aug & Sep \\
\hline $0.0-$ & 1 & 1 & 1 & - & 一 & 一 & 一 & - & 1 & 1 & 1 & - \\
\hline $1.0-$ & - & 1 & 1 & - & - & - & 一 & - & 1 & 一 & 1 & 1 \\
\hline $2.0-$ & 1 & - & - & - & 1 & - & 5 & - & 2 & 2 & 3 & - \\
\hline $3.0-$ & - & 1 & - & - & - & - & - & 3 & 1 & - & - & - \\
\hline $4.0-$ & 一 & - & - & 1 & - & - & 一 & 3 & - & - & 1. & - \\
\hline $5.0-$ & 一 & - & - & - & 一 & - & 1 & 2 & - & - & - & - \\
\hline $6.0-$ & - & - & - & 1 & - & - & - & 1 & - & 一 & - & - \\
\hline
\end{tabular}

* Deterioration by 2 or 3 steps in the 7-point comfort scale. 
TABLE 7. Seasonal effect in afternoon thermal comfort deterioration, in relation to effectivo temperature $\left(T_{\text {eff }}\right)$.

\begin{tabular}{lcccccccccccc}
$\begin{array}{l}\triangle \mathrm{T} \text { Tef } \\
\text { (afternoon } \\
\text { minus morning }\end{array}$ & 1978 & \multicolumn{11}{c}{$\begin{array}{c}\text { No. of occasions on which deterioration* occurred } \\
1979\end{array}$} \\
$\begin{array}{l}\text { reading) }\left({ }^{\circ} \mathrm{C}\right) \\
\text { Oct }\end{array}$ & Nov. & Dec & Jan & Feb & Mar & Apr & May & Jun & Jul & Aug & Sep \\
\hline $0.0-$ & - & 1 & 2 & - & - & - & - & - & 2 & 1 & 2 & - \\
$1.0-$ & 2 & 2 & - & - & - & - & 2 & 1 & 2 & 1 & 4 & 1 \\
$2.0-$ & - & - & - & 1 & 1 & - & 2 & 4 & 1 & 1 & - & - \\
$3.0-$ & - & - & - & - & - & - & 2 & 4 & - & - & - & - \\
$4.0-$ & - & - & - & 1 & - & - & - & - & - & - & - & - \\
\hline
\end{tabular}

* by 2 or 3 steps in the 7 - point scale of thermal comfort

$T_{\text {eff }}$ showed this in a less clear cut way than DBT did.

\section{Discussion}

The seasonal variation in temperature recorded during the present study at Peradeniya was fairly typical of that shown by meteorological records for Kandy. The mean monthly DBT for Kandy, calculated as a 30-year average for the period $1931-1960$, is as follows:- $\operatorname{Jan} 23.1^{\circ} \mathrm{C}$; Feb $23.8^{\circ} \mathrm{C}$; $\operatorname{Mar} 25.2^{\circ} \mathrm{C}$; $\operatorname{Apr} 26.0^{\circ} \mathrm{C}$; May $25.7^{\circ} \mathrm{C}$; Jun $24.6^{\circ} \mathrm{C}$; Jul $24.1^{\circ} \mathrm{C}$; Aug $24.4^{\circ} \mathrm{C}$; Sep $23.8^{\circ} \mathrm{C}$; Oct $24.8^{\circ} \mathrm{C}$; Nov $23.9^{\circ} \mathrm{C}$; Dec $23.2^{\circ} \mathrm{C}$. The same pattern is shown in the ambient temperature recordings in the present study. The correlation between the 12 median values in Table 1 and the 12 meteorological monthly values given above was $r=+0.92$. The absolute level of the ambient temperature readings in Table 1 is higher than in the meteorological series because the readings were made at $9.30 \mathrm{~h}$ while the meteorological values are averages from daily records of maximum and minimum temperature readings taken at $8.30 \mathrm{~h}$ and $17.30 \mathrm{~h}$ local time.

The results show that there is a seasonal effect on thermal comfort even in a climate in which the seasonal variation in temperature is relatively small. The comfort temperature in the warmest month, April, was about $27.5^{\circ} \mathrm{C} \mathrm{DBT}$, while in the least warm months, in and around January, it was about $25.3^{\circ} \mathrm{C}$. These figures are practically identical with those for the average ambient DBT. Thus, as the prevailing ambient temperature rises seasonally, the tolerance level for thermal comfort àlso rises.

The subject is unaware of this seasonal acclimatization. In fact he is aware of the discomfort of the hot season and the comfort of the cool season. In Colombo, in April, "the heat in close apartments becomes extreme and every living 
creature flies to the shade from the suffocating glare of mid-day"; in December "the morning and the afternoon are again enjoyable in the open air". ${ }^{10}$ Discomfort arises when the ambient temperature increases on hot days and in hot afternoons, or when other factors, such as radiant heat, humidity, stillness of the air, muscular activity, clothing, and psychological factors including expectations, affect the situation.

Skin temperature is known to be a prime determinant of thermal comfort in the sedentary state.$^{3,12}$ It is possible that the seasonal acclimatization in thermal comfort is achieved by maintaining the skin temperature at its usual level of about $33^{\circ} \mathrm{C}$ by compensatory adjustments in skin blood flow and sweat output. Data are not available to prove this hypothesis.

Diurnal changes in thermal comfort in the tropics usually consist of a deterioration of comfort in the afternoon and an improvement in the night and early morning. They are associated with corresponding changes in ambient temperature. The association is, however, not strong enough to enable us to predict the degree of change in thermal comfort with much certainty, especially in climates where the diurnal ambient temperature change is relatively small. In Peradeniya, the median differences in DBT between afternoon and morning, as recorded in 134 pairs of indoor readings at $9.30 \mathrm{~h}$ and $14.30 \mathrm{~h}$ in Oct. 1978 - Sep. 1979, were as follows: Oct. $0.83^{\circ} \mathrm{C}$; Nov. $0.94^{\circ} \mathrm{C}$; Dec. $1.28^{\circ} \mathrm{C}$; Jan. $2.22^{\circ} \mathrm{C}$; Apr. $3.11^{\circ} \mathrm{C}$; May $3.83^{\circ} \mathrm{C}$; Jun. $1.50^{\circ} \mathrm{C}$; Aug. $1.67^{\circ} \mathrm{C}$; Sep. $1.39^{\circ} \mathrm{C}$. The largest differences were $6.7^{\circ} \mathrm{C}$ (on a day in May) and $-1.5^{\circ} \mathrm{C}$ (i.e. afternoon cooler, on a day in June). With morning-afternoon temperature differences of this order of magnitude during the year, the morning - afternoon thermal comfort differences could only be broadly related to ambient temperature change. An increase of DBT by $1^{\circ} \mathrm{C}$ could be accompanied by a one-, two-, or three-step deterioration in thermal comfort or a one- or two-step improvement (Table 4). Presumably other factors such as radiant heat, humidity and air movement affect the result, but these could not be evaluated for their separate contributions to thermal comfort. Radiant heat did not seem to be an important variable; globe thermometer readings showed negligible differences from dry bulb thermometer readings, as has been noticed in Singapore too. ${ }^{11}$

The diurnal effect is influenced by season. In the warmer season, April and May, a bigger increase of afternoon temperature than in the less warm months was required to produce a deterioration in thermal comfort. The physiological basis for this effect is not known. It is possible that the same mechanism which produces seasonal acclimatization also produces this seasonal-on-diurnal acclimatization, such as a compensatory increase in vasodilatation and sweat output which preserve the skin temperature at comfort levels over a wider span of increasing ambient temperature. 
The question of superiority of the effective temperature $\left(T_{\text {eff }}\right)$ over dry bulb temperature (DBT) as an indicator of thermal comfort in certain climatic conditions remains controversial. $T_{\text {eff }}$ is an index which was devised in $1920 \mathrm{~s}$ in order to take into account not only DBT but also two other atmospheric factors which affected comfort, viz. humidity and air movement. Furthermore the $T_{\text {eff }}$ scale was meant to give due weightage to the influence upon thermal comfort of even small changes of humidity and air movement. Later studies showed that the $\mathrm{T}_{\text {eff }}$ scale is generally satisfactory for predicting objective physiological strain (judged by sweat output) in ordinary warm atmospheres. ${ }^{8}$ But as a predictor of the subjective feeling of thermal comfort in tropical warmth, $T_{\text {eff }}$ has failed to show superiority over ordinary DBT. In climatic chamber experiments in which sedentary subjects were exposed to an ambient temperature which rose from an initial level of $70^{\circ} \mathrm{F}$ to a final level of $120^{\circ} \mathrm{F}$ in $2.5 \mathrm{~h}$ thermal discomfort was found to be better related to DBT than to $\mathrm{T}_{\mathrm{eff}}{ }^{3}$. In natural outdoor and indoor conditions in Calcutta it has been noticed that $T_{\text {eff }}$ is hardly better than DBT for predicting thermal comfort. ${ }^{7}$ In Singapore, however, $T_{\text {eff }}$ was found to be a better index than DBT for predicting thermal comfort indoors. ${ }^{5}$ In the present study $T_{\text {eff }}$ was found to be no better than DBT in demonstrating diurnal and seasonal effects upon thermal comfort. Perhaps $T_{\text {eff }}$ would outclass DBT in conditions where air movement is considerable. Natural outdoor air movement in equatorial climates is often small, and it is still less indoors during daytime. ${ }^{11}$ The mean speed in the 170 readings made at $9.30 \mathrm{~h}$ was $0.16 \mathrm{~m} / \mathrm{s}$ SD $0.094 \mathrm{~m} / \mathrm{s}(32 \mathrm{ft} / \mathrm{min}$. $\mathrm{SD} 18.5 \mathrm{ft} / \mathrm{min}$ ). As to the influence of humidity, the effective temperature scale assumes that thermal comfort improves when relative humidity falls. It is questionable whether this is so for peoples living in humid climates. It may be worth exploring whether it is the other way around for them, i.e. whether relative humidity may contribute to thermal comfort. When ambient temperature is rising, discomfort sets in slowly in highly humid air and abruptly in moderately humid air. ${ }^{3}$ Effective temperature could therefore be a poorer indicator of thermal comfort than is the dry bulb temperature on days when the diurnal swing in relative humidity is large. The average relative humidity in Sri Lanka is about 80 per cent and the daily variation is small, e.g. a relative humidity of $75 \%$ by day and $90 \%$ by night. But in the warm season the afternoon relative humidity in Peradeniya often falls to $50 \%$ or even $40 \%$, and this is accompanied by thermal discomfort which has a 'dry heat' quality. Wet bulb temperature (WBT), which falls below DBT as the humidity falls, was a poor indicator of thermal comfort.

The 'equatorial comfort index 'ECI',11 which is an adaptation of the effective temperature scale for equatorial climates, could not be systematically used in the present work because its lower limit of $75^{\circ} \mathrm{F}$ was above the level of many of the readings for ambient temperature, especially wet bulb readings. For such ECI readings as could be taken in the present work, the same patterns of seasonal 
acclimatization were visible as with DBT and $T_{\text {eff. }}$ There were slight indications that ECI might be a better predictor of afternoon thermal discomfort.

\section{References}

1. Collins, K. J. (1981). Assessment of thermal comfort. In: Weiner, J. S. \& Lourie, J. A. (eds), Practical human biology, p. 321-331. London: Academic Press.

2. DavY, J. (1821). An account of the interior of Ceylon and of its inhabitants. With travels in that island. p. 49. London: Longman, Hurst, Rees, Orme \& Brown.

3. Drysdale, J. W. (1950) - Climate and design of buildings, Physiological study no. 2. A short study of the effects of summer conditions on human beings made during 1950. Sydney: Commonwealth Experimental Building Station.

4. Elis, F. P. (1952). Thermal comfort in warm, humid atmospheres. Observations in a warship in the tropics. J. Hyg. Camb., 50, 415-432.

5. Eluis, F. P. (1953). Thermal comfort. in warm and humid atmospheres. Observations on groups and individuals in Singapore. J. Hyg. Camb. 51: 386-404.

6. Mrleer, A. A. (1953). Climatology. 8 ed. London: Methuen.

7. RAo, M. N. (1952). Comfort range in tropical Calcutta. a preliminary experiment. Indian J. med. Res., 40: 45-52.

8. Sмith, F. E. (1955). Indices of heat stress, M.R.C. memo. no. 29. London: HMSO

9. SRI LANKa. (1979). Statistical abstract of the Democratic Socialist Republic of Sri Lanka 1977. Department of Census \& Statistics. Colombo: Government Publications Bureau.

10. Tennent, J. E. Ceylon: an account of the island physical, historical and topographical, with notices of its natural history, antiquities and productions. (1st ed. 1859). Reprint of the 6th ed., vol. 1, p. 46. Dehiwela: Sri Lanka Tisara Prakasakayo, 1977.

11. WeBs, C. G. (1961). The diurnal variation of warmth and discomfort in some buildings in Singapore. Ann. Occup. Hyg., 3: 205-213.

12. Winslow, C-E. A. \& Herrington, L. P. (1949). Temperature and human life Princeton University Press.

13. Wyndham, C. H. (1963). Thermal comfort in the hot humid tropics of Australia. J. Ind. Med., 20: 110-117. 